\title{
Effect of Intraperitoneal Injection of Bisphenol-A on Egg Production and Quality Traits in Japanese Quail
}

\author{
Abdel-Rahim, W. M.; A. M. Hanafy; A. M. Abdel-Ghany" and H. A. Khalil \\ Animal Production Department, Faculty of Agriculture, Suez Canal University, 41522, Ismailia, Egypt
}

Received: $25 / 9 / 2017$

\begin{abstract}
This experiment was carried out during winter season 2015, at the Poultry Farm, Department of Animal Production, Faculty of Agriculture, Suez Canal University, Ismailia, Egypt. A total of 40 immature female Japanese quail exposed to different levels of Bisphenol-A (BPA) was examined. Three-week-old, quails were individually weighted and divided into four groups 10 females' birds in each. The BPA was dissolved in corn oil and intraperitoneally injected weekly in the abdominal cavity of quail for three consecutive weeks $\left(3^{\text {rd }}\right.$ through $5^{\text {th }}$ wks old). The experimental groups were treated by a solution containing $(0,1,5$ and $10 \mathrm{mg} \mathrm{BPA} / \mathrm{kg} \mathrm{BW})$. During the experimental period, eggs were collected from each group to estimate egg production and quality traits. At 14 weeks of age, all hens were weighed and then slaughtered in order to collect blood samples to determine serum concentrations of estradiol-17 $\beta$ hormone. The result showed that exposure of female quail before/at puberty to BPA delayed initiation of egg production. While the age at first egg in control female was at 47 days of age, consequently, the BPA treated females were slower to reach $50 \%$ of their final laying rate. The laying rate of eggs in the control not significantly higher than the rate of egg production in all the BPA treatment groups, with the exception of the 10 (mg $\mathrm{BPA} / \mathrm{kg}$ BW group). BPA treated females showed drastically reduced egg quality compared to controls even with a minimal dose of 1 (mg BPA $/ \mathrm{kg} \mathrm{BW}$ group). Shell thickness and internal quality units were significantly linearly decreased, but egg shape index was significantly linearly increased with increased BPA dose compared with control group. The lowest ovarian follicle number and oviduct length were detected in 10 (mg BPA/kg BW group), while the highest values were obtained in 5 (mg BPA/kg BW group). All tested BPA concentrations significantly influenced the egg production and egg quality in female quail indicating a lowest observed effect concentration of 10 (mg $\mathrm{BPA} / \mathrm{kg} \mathrm{BW}$ ). Significant increases of female's body weight and reproductive organ after BPA administration were recorded, as females produced pre-ovulatory follicles at all tested BPA levels it is presumed that BPA did not affect oogenesis but affect the process of ovulation, the highest values of body weight and reproductive organs of females in the 5 (mg BPA/kg BW group), estradiol concentration was increased in BPA-treated groups. It could be concluded that the BPA treatment decreased body weight and delayed puberty and initiation of egg production in female quail. The effect of BPA exposure is proportional to the dose and varies depending on the time of administration.
\end{abstract}

Keywords: Bisphenol-A (BPA), egg production, egg quality, estradiol, Japanese quail

\section{INTRODUCTION}

It is known that sex steroids hormones secreting mainly from gonads and, to a degree, from the adrenals (Ruiz-Cortés, 2012). Reproductive and productive processes depend mainly on gonadal steroids, because of that exogenous/ecological estrogens which target the reproductive system is very risky either economically, vigor and healthiness. Therefore, natural and synthetic estrogen exposure leads to disrupt the homeostasis/balance of sex hormone (Abdelnabi and Ottinger, 2003). In all vertebrates, estradiol is the core potent estrogenic hormone. A common characteristic of the estrogenic compounds is their ability to bind to estrogen receptors (ER) and get the estrogenic responses in target cells (Tollefsen et al., 2002). Pre-puberty events/encounters of birds is probably the most important and critical stages that affects birds' production capabilities later in life (e.g. the onset of sexual maturity in terms of maturation of oocytes, spermatozoa formation, courtship behavior and length and persistence reproduction time).

Although wild birds' populations are normally exposed to combinations of chemical pollutants, it is essential for scientists to determine which of these components are prevailing and responsive to the observed adverse effects. Bisphenol-A (BPA), which is one of these chemical pollutants derived from plastic fabrication, has strong antagonistic effects in birds, even at low doses, causing numerous malformations in the reproductive tract that finally may result in a robust reduction in survival of exposed living birds and animals (Panzica et al., 2009). Since plastic items are normally utilized as a part of the poultry farms, BPA, or one of its metabolites may emerge and be consumed by the growing birds (Hanafy et al., 2005; Escande et al., 2006).

Effects of BPA on body weight have variant trends; Vandenberg et al. (2007) reported increasing of body weight, reproduction and development in humans. While, Furuya et al. (2006) could not be able to report any detectable differences among birds in all evaluated ages. On the contrary, Hanafy et al. (2006, 2007) demonstrated that in birds, upon the BPA injection, among other estrogenic chemicals, to ova or immature male quail, it gives rise to major reprogramming of hepatical yolk precursor genes expression. Halldin et al. (2001) reported that BPA had no considerable effects on the number of eggs produced compared to controls. But interestingly a higher frequency of females with a retained right oviduct in BPA treated groups was reported. 
This manuscript focuses on and targets to reveal the probable potential, later in life, anatomical, physiological and histological effects as a result to intraperitoneal injection on immature Japanese quail with BPA as a simulation to bird's exposure to environmental contaminants that possess endocrine/gonadal disrupting activity (EDCs).

\section{MATERIALS AND METHODS}

\section{Birds and treatments}

This study was carried out during winter season 2015, at the Poultry Farm, Department of Animal Production, Faculty of Agriculture, Suez Canal University, Ismailia, Egypt. Immature female Japanese quails received intraperitoneal injection of BPA for three consecutive weeks started from 3 weeks of age through 5 weeks. Effect of immature exposure to BPA on later productive and reproductive performance was examined.

A total of 100 hatched chicks of Japanese quails (Coternix coternix japonica) were raised on a temperature controlled floor brooder, provided with waterers and feeders. Quails were fed ad libitum on a commercial grower quails' diet during the growing period, contained $24 \%$ crude protein $(\mathrm{CP})$ and 3000 $\mathrm{KCal} \mathrm{ME} / \mathrm{Kg}$ diet. The birds were given continuous light from the initial brooding period until the end of the $5^{\text {th }}$ week. At two-weeks old, a total of 40 immature female quails, approximately similar in body weight $(100 \mathrm{~g} \pm 3.20)$ and free from apparent clinical ailments, were placed on metal cages $(120 \times 60 \mathrm{~cm}$ and $50 \mathrm{~cm}$ height).

After one week from acclimatization, at threeweek-old, these females were individually weighed and divided randomly into four groups of 10 females each. The BPA was dissolved in corn oil and intraperitoneally injected into the abdominal cavity. Birds of the first group received only the vehicle solvent (corn oil) and served as controls. The volume of corn oil injected was kept at $0.1 \mathrm{ml}$ per $100 \mathrm{~g}$ body weight $(\mathrm{BW})$. The other three experimental groups were treated with three graded levels of BPA (i.e. 1, 5 and $10 \mathrm{mg} \mathrm{BPA} / \mathrm{kg} \mathrm{BW}$ ).

From the $6^{\text {th }}$ week, all groups were offered $a d$ libitum water and quail breeder ration $(\mathrm{CP}=18 \%, \mathrm{ME}=$ $2800 \mathrm{KCal})$ with daily illumination for $16 \mathrm{~h}$. photoperiod-schedule. During the experimental period that extended for extra 8 weeks eggs were collected from each group in order to estimate egg production and quality traits. All experimental groups were managed in accordance with the institutional guideline concerning ethics and animal use.

\section{Traits studied}

Female quails were individually weighed at the start of experiment (3 wks.) and at 8, 10, 12 and 14 weeks of age to the nearest $1 \mathrm{~g}$ using an electronic analytical balance. Ages at first egg and at 50\% of hen/day per group production, were determined. Eggs were collected daily to calculate hen/day laying rate. Eggs were weighed individually $(\sim \mathrm{g})$ to estimate egg weight for all treatment groups.
For sake of egg quality measurements, eggs from all experimental groups during the period of 8 through 14 weeks of age were collected biweekly for three consecutive days per investigational group to measure whole egg and egg component weights (egg shell, albumen and yolk). Eggs were broken onto a glass plate to measure both internal and external egg quality characteristics. Before egg breaking, egg length and width were determined by a digital caliper. The heights of yolk and albumen were measured using a micrometer. Hence, egg yolk was carefully separated from albumen by clean towel and weighed. Egg shells were cleaned of any adhering albumen and allowed for dryness. Albumen weight was calculated by subtracting the weight of yolk and shell from the whole egg weight. Shell thickness was measured after egg shell membranes removal from mid-section of the egg shell using a micrometer. Egg shape index, internal Haugh quality unit, yolk index were calculated using the following formulas:

Egg shape index $($ ESI $)=($ Egg width $/$ Egg length $) \times 100$.

$$
\begin{aligned}
& \text { Internal Haugh quality unit }(\mathrm{IQU})=100 \log (\mathrm{H}+4.18- \\
& \left.0.8989 \times \mathrm{W}^{0.6674}\right) \text {. }
\end{aligned}
$$

Where: $\mathrm{H}=$ albumen height $(\mathrm{mm})$ and $\mathrm{W}=$ egg weight $(\mathrm{g})$. Yolk index $(\mathrm{YI})=($ Yolk height $/$ Yolk diameter $) \times 100$

\section{Blood samples}

All birds were weighed before slaughter at 14 weeks of age. To collect blood samples, birds were slaughtered by cutting the jugular vein and blood were collected individually in heparinized glass tubes and centrifuged at $3000 \mathrm{rpm}$ for $15 \mathrm{~min}$. Separated plasma was then stored at $-20^{\circ} \mathrm{C}$ until subsequent estradiol- $17 \beta$ analysis. Concentration of estradiol-17 $\beta$ hormone was determined by human ELISA kits manufactured by DiaMetra, Spello-Perugia, Italy. The sensitivity of the assay was $8.7 \mathrm{pg} / \mathrm{ml}$, the percentage of recovery was 95$100 \%$ and the intra- and inter-assay for estradiol- $17 \beta$ were $9-10 \%$.

\section{Histopathology of oviduct}

The abdominal cavity of the female was opened promptly after slaughtering and the ovary and oviduct were removed and weighed. The number of yellow follicles and the length of oviduct were measured. To assess BPA induced changes in gonadal development, female isthmus and uterus were processed for histological inspection in contrast to controls.

\section{Statistical analysis}

Separate one-way-ANOVA, was applied using SPSS 18 (SPSS, 2009). Differences among means were detected using Duncan's new multiple ranges test (Duncan 1955).

The following model was applied: $\mathbf{Y}_{\mathrm{ij}}=\boldsymbol{\mu}+\mathbf{T}_{\mathbf{i}}+\mathbf{e}_{\mathrm{ij}}$; Where: $\mu=$ the overall mean; $\mathrm{T}_{\mathrm{i}}=$ the observation on the $\mathrm{i}^{\text {th }}$ BPA Treatment (levels $=0,1,5$ and $\left.10 \mathrm{mg}\right) ; \mathrm{e}_{\mathrm{ij}}=$ The random error related to the $j^{\text {th }}$ individual from the $i^{\text {th }}$ BPA Treatment and for testing procedure it is necessary to assume that $\mathrm{e}_{\mathrm{ij}}$ 's are independently and approximately normally distributed, with zero mean and variance equal $\sigma^{2}$ e, $\left\{\right.$ i.e. $\left.\sim \mathrm{NID}\left(0, \sigma^{2} \mathrm{e}\right)\right\}$. 


\section{RESULTS AND DISCUSSION}

Egg production and egg quality traits

The effect immature intraperitoneal administration for three consecutive weeks (at 3,4 and 5 -wk-old) by graded levels of BPA on egg production traits (i.e. age at first egg, age at 50 percentage of production and percentage hen/day laying rate); and egg quality (averages of egg weight, shell thickness, egg shape index, yolk index, and internal Haugh quality units), as well as on the $14^{\text {th }}$ week of age female slaughter weight $(\mathrm{g})$, ovary weight $(\mathrm{g})$, ovary $(\%)$, oviduct weight $(\mathrm{g})$, oviduct $(\%)$, number of ovarian follicle, oviduct length $(\mathrm{cm})$, estradiol concentration $\left(\mathrm{E}_{2}\right.$ $\mathrm{pg} / \mathrm{ml}$ ) traits are shown in Table (1).

Table (1): Effect of immature intraperitoneal injections with different concentration of Bisphenol-A (BPA) on subsequent female Japanese quail average egg production, egg quality traits and reproductive (genital organs weights and percentages) traits

\begin{tabular}{|c|c|c|c|c|c|}
\hline \multirow{3}{*}{ Trait } & \multicolumn{4}{|c|}{ Bisphenol-A (mg/kg BW) } & \multirow{3}{*}{$P$-value } \\
\hline & $\mathbf{0}$ & 1 & 5 & 10 & \\
\hline & (Control) & (T1) & (T2) & (T3) & \\
\hline \multicolumn{6}{|c|}{ Egg production and egg quality traits } \\
\hline Age at First Egg (day) & 47 & 48 & 50 & 52 & -- \\
\hline Age at $50 \%$ (day) & 55 & 60 & 61 & 66 & -- \\
\hline Laying Rate (\%) & $54.36 \pm 3.83^{\mathrm{a}}$ & $46.63 \pm 3.42^{\mathrm{a}}$ & $54.39 \pm 4.03^{\mathrm{a}}$ & $28.01 \pm 2.79^{b}$ & 0.00 \\
\hline Egg Weight (g) & $12.09 \pm 0.34^{b}$ & $11.92 \pm 0.12^{b}$ & $13.00 \pm 0.31^{\mathrm{a}}$ & $11.41 \pm 0.43^{b}$ & 0.01 \\
\hline Shell Thickness $(\mu \mathrm{m})$ & $17.00 \pm 0.55^{\mathrm{a}}$ & $15.36 \pm 0.55^{b}$ & $15.13 \pm 0.41^{\mathrm{b}}$ & $14.09 \pm 0.41^{b}$ & 0.00 \\
\hline Egg Shape Index & $77.50 \pm 0.69^{b}$ & $80.13 \pm 0.84^{\mathrm{a}}$ & $80.42 \pm 0.82^{\mathrm{a}}$ & $80.99 \pm 1.09^{\mathrm{a}}$ & 0.02 \\
\hline Yolk Index & $42.15 \pm 0.75^{\mathrm{a}}$ & $44.10 \pm 0.47^{\mathrm{a}}$ & $43.80 \pm 0.65^{\mathrm{a}}$ & $39.80 \pm 1.12^{b}$ & 0.00 \\
\hline Haugh Unit ${ }^{\dagger}$ & $98.12 \pm 0.50^{\mathrm{a}}$ & $96.79 \pm 0.68^{a b}$ & $95.63 \pm 1.02^{b}$ & $92.26 \pm 1.17^{\mathrm{c}}$ & 0.00 \\
\hline
\end{tabular}

Reproductive traits the $14^{\text {th }}$ week of age

\begin{tabular}{|c|c|c|c|c|c|}
\hline $\begin{array}{l}\text { Female slaughter } \\
\text { Weight (g) }\end{array}$ & $262.4 \pm 4.96^{\mathrm{b}}$ & $267.2 \pm 6.12^{a b}$ & $287.2 \pm 7.71^{\mathrm{a}}$ & $261.2 \pm 11.15^{b}$ & 0.05 \\
\hline Ovary Weight (g) & $7.87 \pm 0.34$ & $7.17 \pm 0.42$ & $9.75 \pm 1.35$ & $6.95 \pm 0.95$ & 0.14 \\
\hline $\operatorname{Ovary}^{¥}(\%)$ & $3.01 \pm 0.17$ & $2.69 \pm 0.16$ & $3.36 \pm 0.40$ & $2.68 \pm 0.38$ & 0.35 \\
\hline Oviduct Weight (g) & $8.04 \pm 0.32$ & $7.52 \pm 0.45$ & $10.35 \pm 2.05$ & $8.09 \pm 0.92$ & 0.35 \\
\hline Oviduct $^{*}(\%)$ & $3.07 \pm 0.11$ & $2.81 \pm 0.14$ & $3.54 \pm 0.61$ & $3.07 \pm 0.25$ & 0.51 \\
\hline № of Ovarian Follicle & $4.00 \pm 0.00^{\mathrm{ab}}$ & $4.00 \pm 0.00^{\mathrm{ab}}$ & $4.60 \pm 0.24^{\mathrm{a}}$ & $3.80 \pm 0.37^{b}$ & 0.05 \\
\hline Oviduct Length (cm) & $39.40 \pm 1.50^{\mathrm{ab}}$ & $39.80 \pm 1.20^{\mathrm{ab}}$ & $43.40 \pm 3.43^{\mathrm{a}}$ & $36.3 \pm 0.86^{\mathrm{b}}$ & 0.05 \\
\hline Estradiol (pg/ml) & $105.26 \pm 10.94$ & $161.93 \pm 39.50$ & $174.71 \pm 67.59$ & $190.26 \pm 56.32$ & 0.64 \\
\hline
\end{tabular}

From Table (1), egg production and quality traits (i.e. Laying Rate\%; Egg Weight, g; Shell Thickness, $\mu \mathrm{m}$; Egg Shape Index; Yolk Index) altered significantly, with the intraperitoneal injection of juvenile female quails with graded concentration of Bisphenol-A.

Haugh Unit Outcomes, seems to be fluctuated with the administered of juvenile female quail doses of BPA and seems to have dose-independent competence of egg production and quality traits (Table 1).

Results revealed also that immature BPA exposure of female quail caused 1-5 days delaying of produce eggs in treated groups, in per-group-sexualmaturity (i.e. Age at First Egg). While the per-group age at first egg in controls was at 47 days of age, BPA treated females were slower (48, 50 and 52 days) to begin egg production as group 1,5 and $10(\mathrm{mg} \mathrm{BPA} / \mathrm{kg}$ BW groups), respectively. Consequently, the BPA treated females were slower to reach $50 \%$ of their hen/day laying rate, while control group reached $50 \%$ percentage rate hen/day egg production at 55 days of age. However, females in 1,5 and $10(\mathrm{mg} \mathrm{BPA} / \mathrm{kg} \mathrm{BW}$ groups) did not reach their 50\% laying rate until they were 60,61 and 66 days of age, respectively. 
BPA administrations proved that, as a pollutant, it can influence many forms of reproduction and production activities and likewise has impacts at low doses, in the light of the fact that even little changes in hormone concentration can have biologically important consequences. Similar results have been reported by Ottinger et al. (2002) who showed that female Japanese quail exposed to in ova $20 \mu \mathrm{g} / \mathrm{egg}$ estradiol benzoate has a more prolonged period.

Also, Oshima et al. (2012) found that bisphenolA have the dose-independent ability to cause ovotestis in the Japanese quail embryo. In fish, the percentage of ovulated brown trout females was similar for the control group and the groups exposed to BPA concentrations of 1.75 and $2.40 \mu \mathrm{g} / \mathrm{L}$, whereas at BPA concentrations of $5.00 \mu \mathrm{g} / \mathrm{L}$ females did not ovulate through the investigation (Lahnsteiner et al., 2005).

The laying rate showed likewise oscillated or dose liberated effect and in the controls was $54.36 \%$, and this was not significantly higher than the rate of egg production in all the BPA treatment groups, with the exception of the $10 \mathrm{mg} \mathrm{BPA} / \mathrm{kg} \mathrm{BW}$ group (Table 1). The only dose of BPA that highly significantly $(\mathrm{P} \leq$ 0.001 ) impaired egg production was the $10 \mathrm{mg} / \mathrm{kg} \mathrm{BW}$ and that was probably because of greater endocrinedisrupting mechanism leading to extensively reduced the total number of ovarian follicles with a higher apparent malformation to the oviduct (Figures 4 and 8).

Berg et al. (2001) injected quail eggs by $200 \mu \mathrm{g}$ of BPA/g egg and found an abnormal oviduct in females suggested that mechanism of endocrine-disrupting may led to these effects and that reproduction was probably to be impaired. On the other hand, embryonic treatment of female quails to 67 or $200 \mu \mathrm{g} / \mathrm{g}$ egg of BPA had no significant effects on egg production as compared with controls (Halldin et al., 2001).

As revealed in Table (1) BPA treated females showed variable degrees of reduction in egg quality traits (i.e. Shell Thickness, $\mu \mathrm{m}$; Egg Shape Index; Yolk Index and Haugh Unit), compared to controls even with the minimal dose of $1 \mathrm{mg} \mathrm{BPA} / \mathrm{kg}$ BW group. These inhibitory impacts showed in a fluctuated doseindependent manner. In this respect, Shell thickness and internal quality (Haugh units) were generally decreased significantly, but egg shape index, however and apart from the various BPA doses, significantly increased with the administration of the BPA.

\section{Reproductive traits}

From reproductive traits at the $14^{\text {th }}$ week of age of Table (1) female slaughter weight ( $g$ ) number of ovarian follicle and oviduct length $(\mathrm{cm})$ altered significantly $(\mathrm{P} \leq 0.05)$, with the intraperitoneal injection of juvenile female quails with graded concentration of Bisphenol-A. On the other hand, ovary weight (g); ovary $(\%)$; oviduct weight $(\mathrm{g})$; oviduct $(\%)$; estradiol $(\mathrm{pg} / \mathrm{ml})$ were not affected significantly, with the intraperitoneal injection of juvenile female quails with graded concentration of Bisphenol-A.

All traits that have been altered significantly (i.e. female slaughter weight; number of ovarian follicle and oviduct length), seemed to have dose-independent response and have no obvious trend that can be stated herein. This inconsistent fluctuated drift may be characteristic to this pollutant (Berg et al., 2001); or it is because of the low sample size applied herein (Number of observation per group $=10$ ). Another explanation is that this fluctuated effect is recognized as nonmonotonic-dose-response-curves (NMDRCs), which are usually reported in pharmacology in response to treatment with EDCs that interact with receptors (Magyar, 2011).

Though immature intraperitoneal administration of Bisphenol-A caused significant alteration on the whole length $(\mathrm{cm})$, it has not reveal same effect on oviduct weights or percentages. This may mean that this augment in length was not associated similar boost or amplification on the cellular level of the different component of oviduct, or perhaps inconsistent cellular growth, which may be revealed when dealing with the histological sections from isthmus and uterus that will be presented afterwards.

Similarly, Hermansson et al. (2007) reported that body weight in hens exposed to $60 \mu \mathrm{g} / \mathrm{g}$ egg Ethinyl estradiol (EE) was significantly higher compared to control hens. In contrast, embryonic treatment of female quail to 67 or $200 \mu \mathrm{g} / \mathrm{g}$ egg of BPA had no significant effects on body weight and weight of the left oviduct as compared with control (Halldin et al., 2001; Furuya et al., 2006). They concluded that the body weight did not show any differences among all ages of birds, though the growth of different organs was affected significantly in chicks even with at low doses of $2 \mu \mathrm{g} \mathrm{BPA} / \mathrm{kg}$. Oral administration of 0.01 to $0.1 \mathrm{mg} / \mathrm{kg}$ Diethylstilbestrol, which was began with the first day of hatching had no effect on the body weights of both male and female adult quails (Yoshimura et al., 2000). In a similar study, comparison of doses from BPA and DDT did not produce any impacts on the tested female quails (ElGawish et al., 2008).

Though of insignificant effect on E2 concentrations, (Table 1) Intraperitoneal injections of BPA, as an estrogen disrupting compound, proved that it can have biologically important consequences on the reproductive system appearance (i.e. number of ovarian follicle; oviduct length) and body metabolism (female slaughter weight at the 14 th week of age), even at miniature doses, which reflects its environmental impacts. These impacts should be considered in mind as its consequences not only on the productivity of domesticated birds, but also on the wild birds and the world biodiversity.

Nunez et al. (2001) stated that in adult ovariectomized female rats treated with 4 or $5 \mathrm{mg}$ /day BPA for 15 days, showed a significant decrease of body weight gain with normal food intake. The difference between the results among the previous literature might be attributed to the difference in exposing period and age sensitivity to BPA toxicity and the cytochrome P450 enzyme level among the different species. The level of cytochrome $P 450$ enzymes in humans, chicken, and quail livers is not high, thus they have lower catalytic activity than rats. Therefore, the compound stays a longer period in the body leading to greater 
access to target tissues (Hansen et al., 2011). Hence, quails are more sensitive to BPA compared with other species. Collectively, the time of exposure is important factor to provoke the effect of EDCs on birds.

As females produced pre-ovulatory follicles at all tested BPA levels it is presumed that BPA did not affect oogenesis but the process of ovulation Table (1). Similarly, Ethinylestradiol (EE), another endocrine disruptor, stimulated egg production at low doses and inhibited egg production at higher doses in the fathead minnow (P. promelas) (Jobling et al., 2003).

There is, however, no such organ or system in the body that is not controlled in some way or another by the endocrine system. Hence, while the estrogenic hormone is often studied for its effects on the reproductive system of female and secondary sex characteristics, in male, estrogens are likewise responsible for keeping females' reproductive health, bone density, cardiovascular health, and the immune system (Wend et al., 2012). Natural hormones are recognized according to follow certain biological rules, and it consequently follows that substances that mimic or block (EDCs) the activities of hormones would likewise follow similar rules. The question is how long the study of EDCs will continue to benefit from progress in science of environmental health, which works at the intersection of multiple area counting ecology, endocrinology, and toxicology. In the current study, the highest values of body weight and reproductive organs of females in the $5(\mathrm{mg} \mathrm{BPA} / \mathrm{kg}$ BW group) may be attributed to the dose effect of BPA. This effect is recognized as non-monotonic dose response curves (NMDRCs), which are usually reported in pharmacology in response to treatment with EDCs that interact with receptors (Magyar, 2011). However, yet for a considerable years there has been discussion about NMDRCs from EDCs exposures and whether they are safe in their different current uses (Vandenberg et al., 2009), including that NMDRCs could be specific

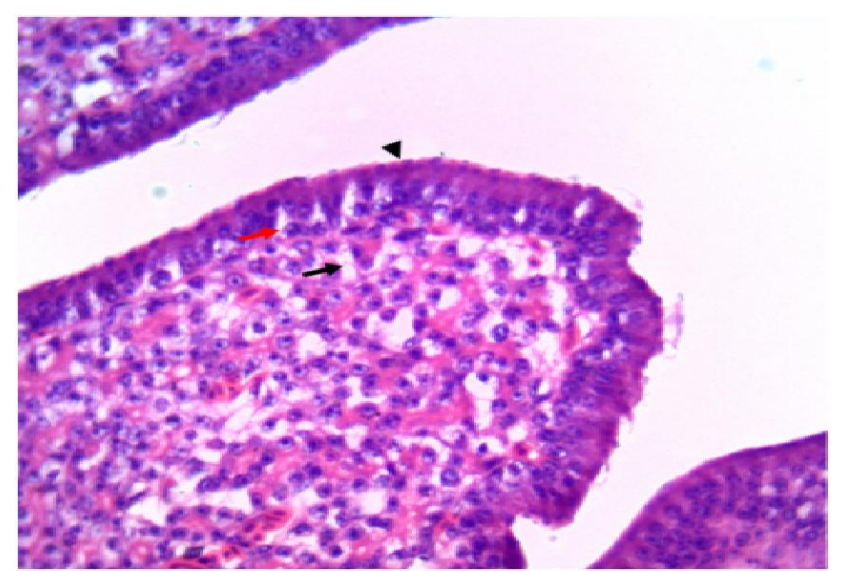

Figure (1): Isthmus from control group. to only a little EDCs and accordingly without broader importance. Previous author discovered cases of NMDRCs in laboratory animals and in human populations for more than 70 EDCs from a range of chemical classes and suggested that BPA is one of these substances (Vandenberg et al., 2013).

\section{Histology of oviduct \\ Isthmus}

Sections from isthmus of the control group (Figure 1). No changes were seen on administration of 1 (mg BPA /kg BW group) (Figure 2). Figure (3) showed effect of administration of 5 (mg BPA $/ \mathrm{kg} \mathrm{BW}$ group) on isthmus. Superficial atrophic single layer of lining epithelium (Red arrow), with several hyperplastic disorganized basal cells (Arrow heads). Edematous chronically inflamed lamina propria is evident (Long black arrows), disfigurement of some papillary fronds is seen (about 30\%), in which lining epithelium changed into a single layer of superficial atrophic epithelial cells, with eosinophilic cytoplasm and small dark nuclei, with several hyperplastic disorganized basal cells. Abundant lymphocytic infiltrate extends from underlying edematous inflamed lamina propria, permeating the overlying epithelium (Figure 3).

On administration of 10 (mg BPA $/ \mathrm{kg}$ BW group), about $80 \%$ of papillary fronds show disfigurement changes, in which epithelial lining changed into a single layer of atrophic epithelial cells, with eosinophilic cytoplasm and small dark nuclei. Moreover, marked inflammatory cell infiltrate, congested blood vessels and prominent edema are seen in underlying lamina propria. Epithelial lining changed into a single layer of atrophic superficial epithelial cells, with eosinophilic cytoplasm and small dark nuclei (Red arrows), with several hyperplastic disorganized basal cells (Black arrows). Marked inflammatory cell infiltrate, congested blood vessels (Arrow head) and prominent edema are seen in underlying lamina propria (Figure 4).

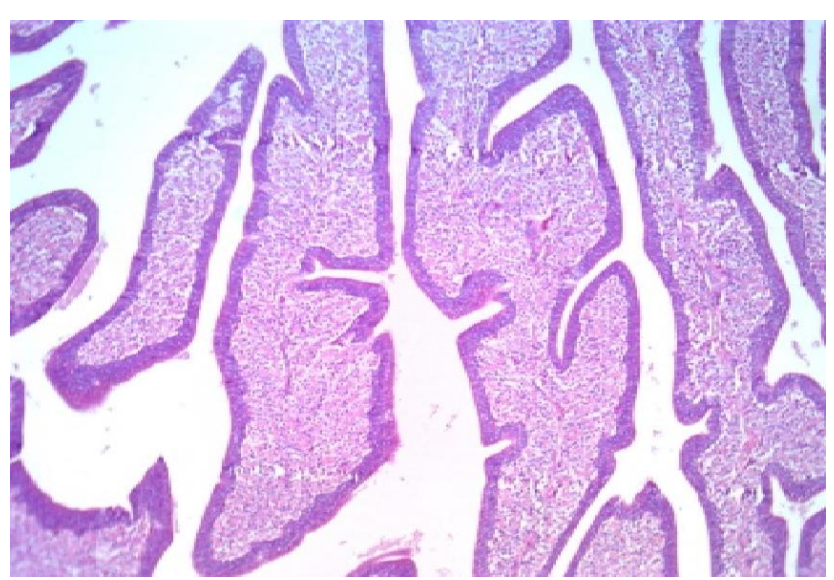

Figure (2): Isthmus from 1 (mg BPA / kg BW group). 


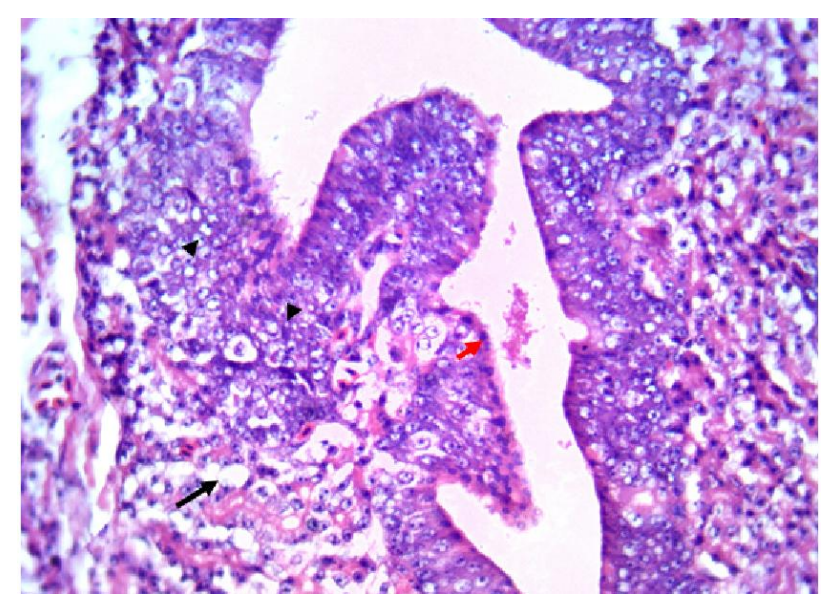

Figure (3): Isthmus from 5 (mg BPA / kg BW group).

\section{Uterus}

Figure (5) showed uterus section from control group. In Figure (6) compared to control group, on administration of 1 (mg BPA $/ \mathrm{kg}$ BW group), uterine mucosal glands show focal areas of irregular distribution, edema and hemorrhage, glandular distortion, hemorrhage and stromal edema (Black arrow). In Figure (7) on administration of 5 (mg BPA $/ \mathrm{kg}$ BW group), similar pathological changes were noted, as observed with administration of 1 (mg BPA $/ \mathrm{kg}$ BW group) glandular distortion, hemorrhage and stromal edema (Black arrow). In Figure (8) on administration of 10 (mg BPA/ $\mathrm{kg}$ BW group), similar

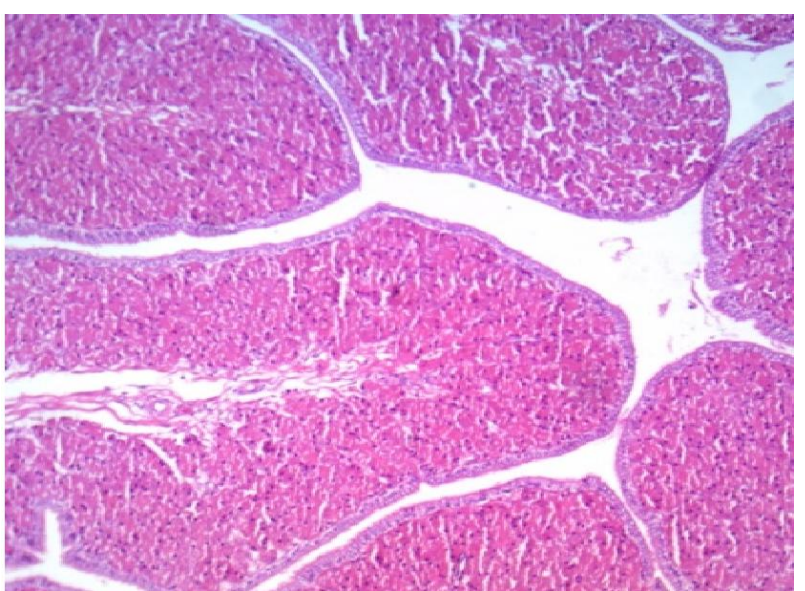

Figure (5): Uterine control group.

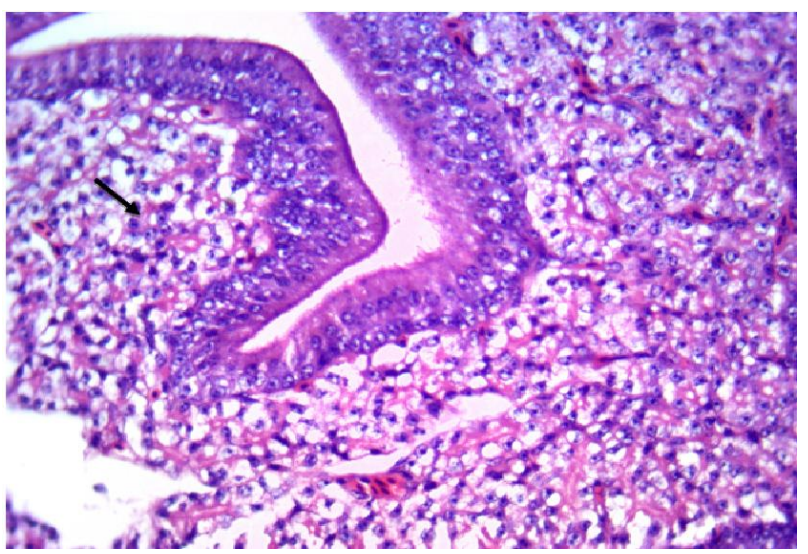

Figure (7): Uterus 5 (mg BPA /kg BW group).

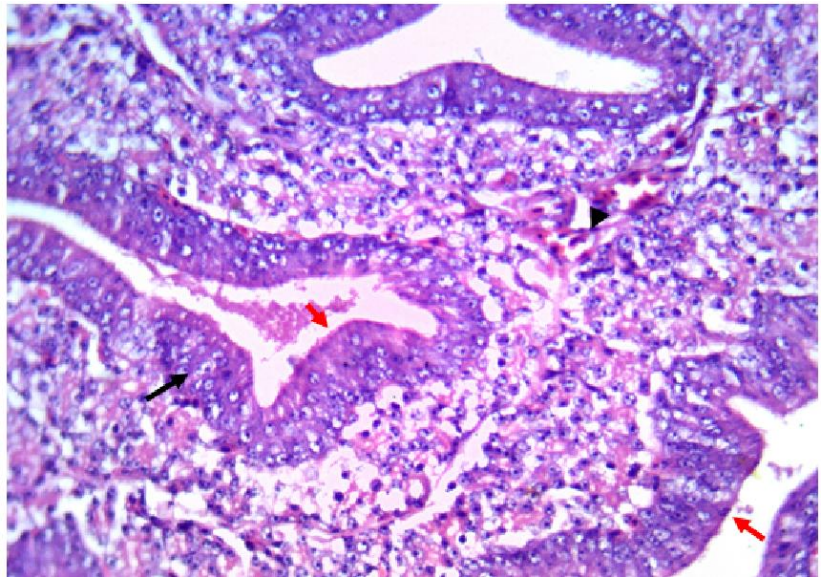

Figure (4): Isthmus from 10 (mg BPA / kg BW group).

pathological changes were noted, as observed with administration of 1 and 5 ( $\mathrm{mg} \mathrm{BPA} / \mathrm{kg} \mathrm{BW}$ groups), glandular distortion, hemorrhage and stromal edema (Black arrow).

In avian species, female reproductive function depends upon the control of ovarian steroid hormones that enables follicular development, ovulation, and oviposition. It is suggested that exposure of the developing reproductive system to EDCs can disrupt oogenesis, folliculargenesis and/or oviduct development acting through estrogenic, ant-estrogenic, and/ or antiandrogenic effects.

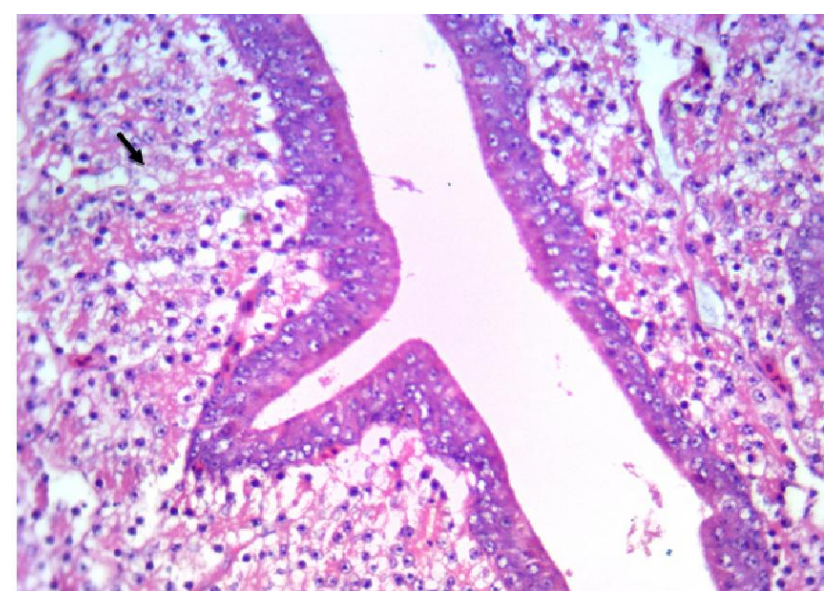

Figure (6): Uterus 1 (mg BPA /kg BW group).

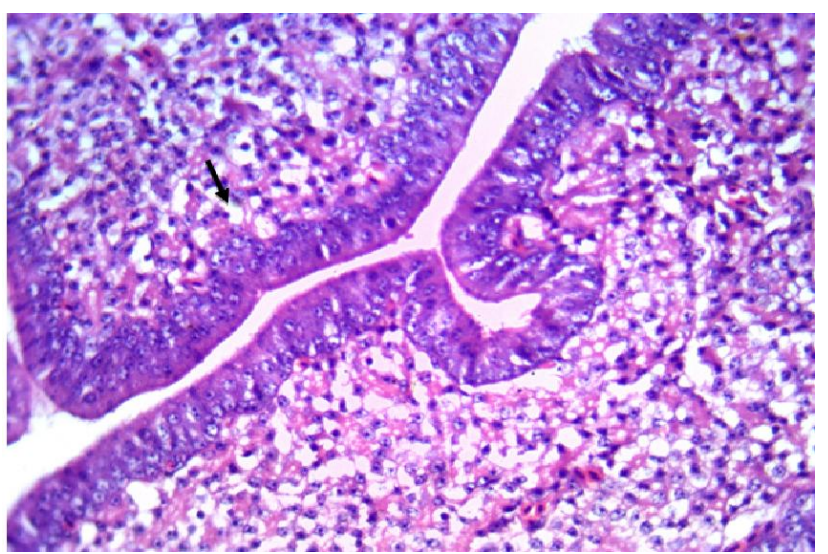

Figure (8): Uterus 10 (mg BPA /kg BW group). 


\section{CONCLUSION}

The BPA treatment decreased body weight and delayed puberty and initiation of egg production in female quail. Eggs with thinner shells and reduced egg quality were produced by female quail exposed at puberty to BPA supporting the hypothesis that eggshell thickness may be induced during development and maturation by estrogenic pollutants. Since ovary

\section{REFERENCES}

Abdelnabi, M. A. and M. A. Ottinger (2003). Hypothalamic indolamines during embryonic development and effects of steroid exposure. General and Comparative Endocrinology, 130: 13-19.

Berg, C, K. Halldin and B. Brunstrom (2001). Effects of bisphenol A and tetrabromobisphenol A on sex organ development in quail and chicken embryos. Environmental Toxicology and Chemistry, 20: 2836-2840.

Duncan, D. B. (1955). Multiple Range and Multiple FTests. Biometrics, 11: 1-42.

El-Gawish, R., M. Elshabrawy Ghanem and T. Maeda (2008). Low doses of bisphenol A and o, p'DDT at early stage of life delayed sexual maturity in female Japanese quail. Livestock Research for Rural Development 20(11): Article \#188.

Escande, A., A. Pillon, N. Servant, J. P. Cravedi F. Larrea, P. Muhn, J. C. Nicolas, V. Cavaillès and P. Balaguer (2006). Evaluation of ligand selectivity using reporter cell lines stably expressing estrogen receptor alpha or beta. Biochemical Pharmacology, 71: 1459-1469.

Etches, R. J. (1987). Calcium logistics in the laying hen. Journal of Nutrition, 117: 619-628.

Furuya, M, K. Adachi, S. Kuwahara, K. Ogawa and Y. Tsukamoto (2006). Inhibition of male chick phenotypes and spermatogenesis by bisphenol-A. Life Sciences, 78: 1767-1776.

Halldin, K., C. Berg, A. Bergman, I. Brandt and B. Brunström (2001). Distribution of bisphenol $\mathrm{A}$ and tetrabromobisphenol $\mathrm{A}$ in quail eggs, embryos and laying birds and studies on reproduction variables in adults following in ovo exposure. Archives of Toxicology, 75: 597-603.

Hanafy, A. M., T. Sasanami and M. Mori (2005). Binding of xenoestrogens and phytoestrogens to estrogen receptor $\beta$ of Japanese quail (Coturnix japonica). Journal of Poultry Science, 42: 238-244.

Hanafy, A. M., T. Sasanami and M. Mori (2006). Effects of diethylstilbestrol and ethinylestradiol on gene transcription of very low-density apolipoprotein II in the liver of Japanese quail, Coturnix japonica. Environmental Toxicology and Chemistry, 25: $1354-1359$.

Hanafy, A. M., T. Sasanami and M. Mori (2007). Sensitivity of expression of perivitelline membrane glycoprotein ZP1 mRNA in the function appeared normal in all birds the severe malformations of the left oviduct are the most likely causes behind the total inhibition of egg production. Results confirm that administration of BPA to female Japanese quail at puberty may represent very sensitive stage to test the estrogenic potency of different chemical compounds.

liver of Japanese quail (Coturnix japonica) to estrogenic compounds. Comp. Biochemistry and Physiology Part C: Toxicology and Pharmacology, 144: 356-362.

Hansen, W. M, J. D. Gonzalo and M. C. Sandra (2011). Enzymatic activity in turkey, duck, quail and chicken liver microsomes against four human cytochrome $\mathrm{P} 450$ prototype substrates and aflatoxin B. Xenobiotics. 1:1.

Hermansson, A. (2007). Effects on the reproductive system in domestic fowl (Gallus domesticus) after embryonic exposure to estrogenic substances. Diss. (sammanfattning/summary) Uppsala: Sveriges lantbruksuniv, Acta Universitatis Agriculturae Sueciae, 20: 16526880 .

Isola, J. J. (1987). The effect of progesterone on the localization of progesterone receptors in the nuclei of chick oviduct cells. Cell and Tissue Research, 249:317-23.

Jobling, S., D. Casey, T. Rodgers-Gray, J. Oehlmann, U. Schulte-Oehlmann, S. Pawlowski, T. Baunbeck, A. P. Turner and C. R. Tyler (2003). Comparative responses of molluscs and fish to environmental estrogens and an estrogenic effluent. Aquatic toxicology, 65: 205-220.

Lahnsteiner, F, B. Berger, M. Kletzl and T. Weismann (2005). Effect of bisphenol A on maturation and quality of semen and eggs in the brown trout, Salmo trutta f. fario. Aquatic Toxicology, 75(3): 213-224.

Magyar, K. (2011). The pharmacology of selegiline. International Review of Neurobiology, 100: 65-84.

Nunez, A. A., K. Kannan, J. P. Giesy, J. Fang and L. G. Clemens (2001). Effects of Bisphenol A on energy balance and accumulation in brown adipose tissue in rats. Chemosphere, (42): 917-922.

Oshima, A, R. Yamashita, K. Nakamura, M. Wada and K. Shibuya (2012). In ovo exposure to nonylphenol and bisphenol A resulted in dose-independent feminization of male gonads in japanese quail (Coturnix japonica) embryos. Environmental Toxicology and Chemistry, 31: 1091-1097.

Panzica, G. C., E. Mura, E. D. Miceli, M. A. Martini, S. Gotti and C. Viglietti-Panzica (2009). Effects of xenoestrogens on the differentiation of behaviorally relevant neural circuits in higher vertebrates. Annals of the New York Academy of Sciences, 1163: 271-278. 
Ruiz-Cortés, Z. T. (2012). Gonadal Sex Steroids: Production, Action, and interactions in Mammals. Chapter 1. "Steroids-From Physiology to Clinical Medicine. Sergej M. Ostojic, editors. 3-42.

SPSS, (2009). SPSS Statistics for Windows, Version 18.0. SPSS Inc., USA.

Tollefsen, K. E., R. Mathisen and J. Stenersen (2002). Estrogen Mimics bind with similar affinity and specificity to the hepatic estrogen receptor in Atlantic salmon (Salmo salar) and rainbow trout (Oncorhynchus mykiss). General and Comparative Endocrinology, 126: 14-22.

Vandenberg, L. N., T. Colborn, T. B. Hayes, J. J. Heindel, D. R. Jr Jacobs, D. H. Lee, J. P. Myers, T. Shioda, A. M. Soto, F. S. vom Saal, W. V. Welshons and R. T. Zoeller (2013). Regulatory decisions on endocrine disrupting chemicals should be based on the principles of endocrinology. Reproductive Toxicology, 38C: $1-15$.

Vandenberg, L. N., R. Hauser, M. Marcus, N. Olea and W. V. Welshons (2007). Human exposure to bisphenol A (BPA). Reproductive Toxicology, 24(2): 139-77.

Vandenberg, L. N., M. V. Maffini, C. Sonnenschein, B. S. Rubin and A. M. Soto (2009). Bisphenol-A and the great divide: a review of controversies in the field of endocrine disruption. Endocrinology Reviews, 30: 75-95.

Wend, K., P. Wend and S. A. Krum (2012). TissueSpecific Effects of Loss of Estrogen during Menopause and Aging. Frontiers in Endocrinology, 3:19.

Yoshimura, T., Y. Suzuki, E. Makino, T. Suzuki, A. Kuroiwa, Y. Matsuda, T. Namikawa and S. Ebihara (2000). Molecular analysis of avian circadian clock genes. Brain research. Molecular brain research, 78: 207-215.

\section{اثر حقن البسيفينول أ في التجويف البطنى على الإنتاج وصفات جودة البيض في السمان اليابانى \\ و ائل محمد احمد عبد الرحيم، احمد محمد حنفى، احمد محمود عبد الغنى، حسن احمد عبد الزبد الغفار

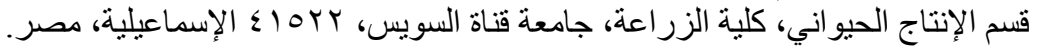

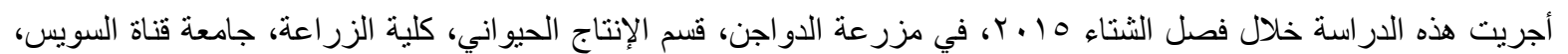

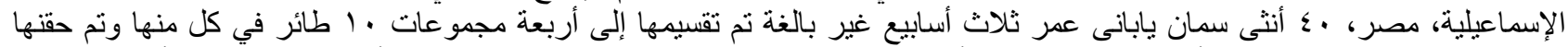

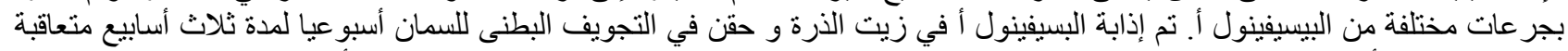

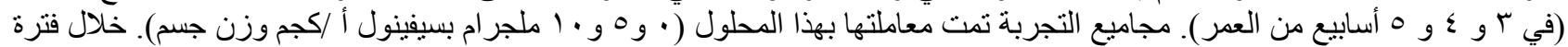

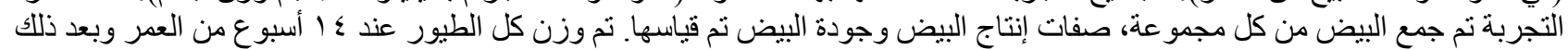

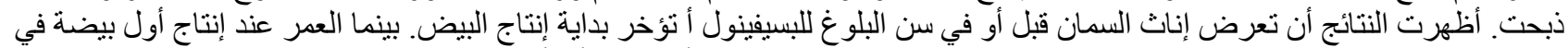

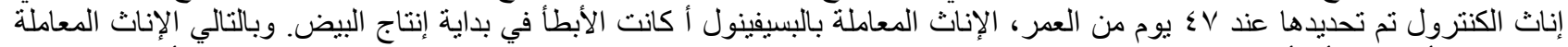

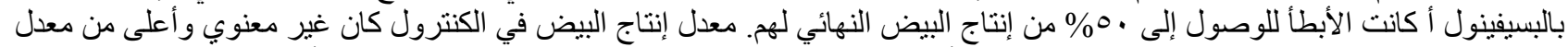

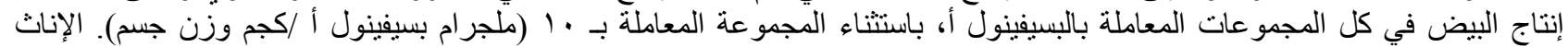



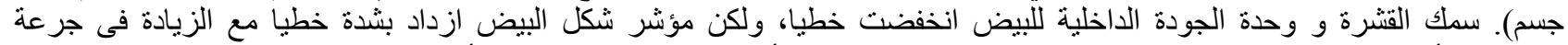

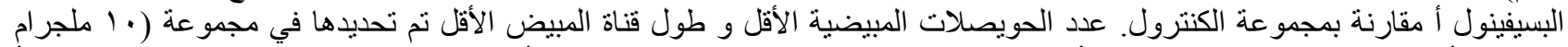

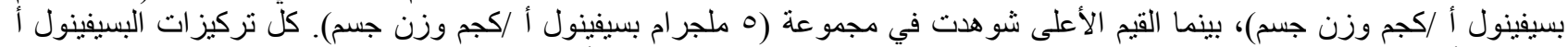

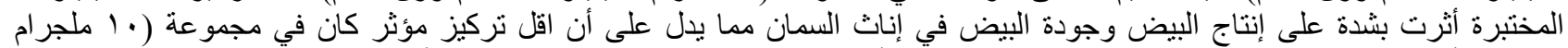

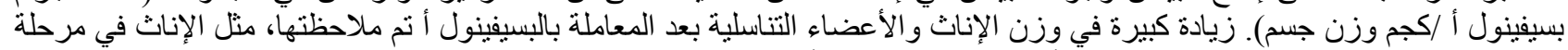

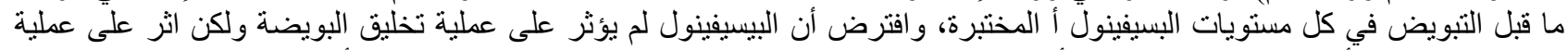

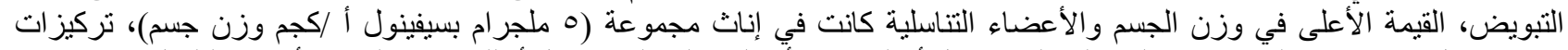

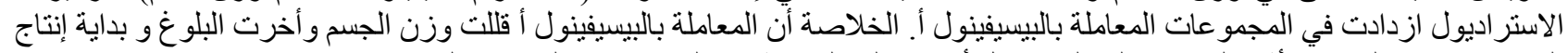

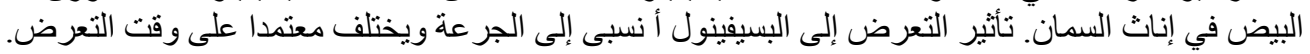
الكلمات المفتاحية: البسيفينول أ، إنتاج البيض، جودة البيض، الاستر اديول، السمان اليابانى. 